\title{
Inheritance and Linkage of Tomato Mottle Virus Resistance Genes Derived from Lycopersicon chilense Accession LA 1932
}

\author{
P.D. Griffiths \\ Department of Horticultural Sciences, New York State Agricultural Experiment Station, Hedrick Hall, \\ Geneva, NY 14456-0462 \\ J.W. Scott \\ Gulf Coast Research and Education Center, Institute of Food and Agricultural Science, University of \\ Florida, 5007 60th Street East, Bradenton, Fl 34203
}

\begin{abstract}
ADDITIONAL INDEX wORDS. Lycopersicon esculentum, disease resistance, heritability, RAPD markers, vegetable breeding
Abstract. Tomato mottle virus (ToMoV) is a silverleaf whitefly (Bemisia argentifolii Bellows and Perring n. sp.) transmitted, bipartite geminivirus that infects tomatoes (Lycopersicon esculentum Mill.). Inbred lines resistant to ToMoV were derived from Lycopersicon chilense Dunal accession LA 1932. Inheritance was studied using a family developed from the crossing of a resistant inbred with a susceptible tomato inbred over two seasons. The $F_{1}$ had resistance intermediate to the parents and generation means analysis of $F_{1}$ and $F_{2}$, backcross and parental populations suggested that the action of at least two additive genes with high heritability $\left(h_{n . s .}^{2}=0.87\right)$ controlled ToMoV resistance. When data from the two seasons were combined, an acceptable fit to an additive-dominance genetic model was obtained. Single plant comparisons, bulk comparisons, and tailends of $F_{2}$ populations segregating for ToMoV resistance derived from $L A 1932$ identified randomly amplified polymorphic DNA (RAPD) markers using eight hundred 10-mer oligonucleotide primers. The $F_{2}$ populations used for inheritance studies were screened for polymorphic markers, and 12 RAPD markers associated with the ToMoV resistant line were linked to the morphological markers self-pruning $(s p)$ and potato leaf $(c)$ on chromosome 6. RAPD markers that were associated with ToMoV resistance segregated into two linked regions flanking either side of the $s p$ and $c$ loci. The molecular studies suggested that the action of at least two additive regions controlled ToMoV resistance which supported the inheritance analysis.
\end{abstract}

The silverleaf whitefly (Bemisia argentifolii) appeared in the Western Hemisphere in the mid-1980s and was able to reproduce and feed more efficiently on tomato (Lycopersicon esculentum) than the local whitefly biotype(s) (Schuster et al., 1990). In 1989 tomato plants with unusual viruslike symptoms were identified in southwestern Florida (Kring et al., 1991) and the pathogen was identified as a unique whitefly-transmitted bipartite geminivirus now known as tomato mottle virus (ToMoV) (Abouzid et al., 1992). More than a dozen whitefly-transmitted geminiviruses that infect tomato have now been identified in the Western Hemisphere (Polston and Anderson, 1997), including tomato yellow leaf curl virus (TVLCV). There are at least five geminiviruses called TYLCV. The best characterized is the monopartite geminivirus known as TYLCV-I (Navot, 1991). TYLCV-I causes extensive losses in the Middle East, and host plant resistance to this pathogen has been studied extensively. Inheritance studies on TYLCV resistance genes have revealed different types of genetic control: partially dominant tolerance genes derived from L. pimpinellifolium (L.) Mill. and L. chilense (Pilowsky and Cohen, 1974; Zamir et al., 1994), a single dominant gene Tylc derived from L. pimpinellifolium (Kasrawi, 1989), a recessive tolerance gene from $L$. cheesmanii Riley (Hassan et al., 1984), a multigenic dominant resistance from $L$. hirsutum Humb and Bonpl. (Hassan et al., 1984), and a recessive tolerance based on five genes from L. peruvianum (L.) Mill. (Pilowsky and Cohen, 1990). A partially dominant major gene (Ty-1) on chro-

Received for publication 22 Feb. 2000. Accepted for publication 6 Apr. 2001. Florida Agricultural Experiment Station journal series R-07389. The cost of publishing this paper was defrayed in part by the payment of page charges. Under postal regulations, this paper therefore must be hereby marked advertisement solely to indicate this fact. mosome 6 of tomato was introgressed from LA 1969 (an accession of L. chilense) and conferred tolerance to TYLCV-I (Zamir et al., 1994). In general, resistance to TYLCV-I has often been inadequate, and control of whiteflies with the systemic insecticide Admire [imidocloprid (Bayer Corp., Kansas City, Mo.)] has been necessary to avoid extensive losses.

No genetic studies have been conducted on bipartite tomato geminiviruses, including ToMoV. ToMoV causes leaf curling, epinasty, stunting of growth, and reduction in leaf size and yield (Abouzid et al., 1992; Polston et al., 1993). In 1990, wild Lycopersicon Mill. sp. were screened for resistance to ToMoV and the best resistance was found in accessions of $L$. chilense (Scott and Schuster, 1991; Scott et al., 1995). Resistance to ToMoV was found in several L. chilense accessions, with the most promising resistant lines derived from accessions LA 1932, LA 1938, LA 1961, LA 1968, and LA 2779. Introgression of resistance into L. esculentum resulted in a low percentage of backcross plants in the higher resistance categories $(3.4 \%)$, suggesting that ToMoV resistance was controlled by more than one gene.

ToMoV resistant lines derived from $L$. chilense have exhibited less severe symptoms in indeterminate $(s p+)$ plants than in determinate ( $s p$ ) plants (Scott et al., 1995) indicating possible linkage of ToMoV resistance to the $s p$ locus on the long arm of chromosome 6 . The presence of susceptible $s p+$ plants indicated that this was not caused by outgrowing the virus. Therefore, the objectives of this investigation were to 1) determine the inheritance of ToMoV resistance derived from LA 1932,2) find randomly amplified polymorphic DNA (RAPD) markers linked to ToMoV resistance genes and 3) compare the presence of markers with $\mathrm{ToMoV}$ disease severity. The $\mathrm{F}_{2}$ populations used in the inheritance studies segregated the $s p$ gene, which provided a 
well-characterized phenotypic marker to detect possible linkage of other markers on chromosome 6.

\section{Materials and Methods}

Germplasm EVAluated. Indeterminate ToMoV resistant inbred Fla. 960719 (719) and determinate resistant inbred Fla. 960729 (729) with potato leaf ( $c$ gene) were derived from $L$. chilense accession LA 1932. Crosses were made between the resistant inbreds and determinate susceptible breeding lines Fla. 7324 (7324) and Fla. 7613 (7613), respectively. The $F_{1}$ plants derived from the $719 \times 7324$ cross were self-pollinated to provide an $\mathrm{F}_{2}$ population segregating for the self-pruning gene ( $s p$ ) and backcrossed to the parents $719\left(\mathrm{P}_{1}\right)$ and $7324\left(\mathrm{P}_{2}\right)$ to obtain backcross populations $\mathrm{BC}_{1}$ and $\mathrm{BC}_{2}$, respectively. The six generations from the $719 \times 7324$ cross were used for inheritance studies, and RAPD polymorphisms associated with ToMoV resistant plants were used to test for linkage to ToMoV resistance in the $\mathrm{F}_{2}$ population. ToMoV resistant line 719 and bulked DNAs from the tailends of the $\mathrm{F}_{2}$ population derived from the $719 \times 7324$ cross were used for identification of RAPD markers. The $F_{2}$ population derived from the $729 \times 7613$ cross was used to study segregation of the potato leaf gene $(c)$ and associated markers.
Indeterminate ToMoV susceptible (960724 (724)), and determinate resistant [960744 (744)] sister lines of 719 were also used in the identification of molecular markers.

InOCULATION. A colony of ToMoV viruliferous whiteflies was maintained on the dwarf tomato 'Florida Lanai' in a controlled temperature room with a 14-h photoperiod under cool white fluorescent lights with irradiance of $50 \mathrm{mmol} \cdot \mathrm{m}^{-2} \cdot \mathrm{s}^{-1}$ at $25^{\circ} \mathrm{C}$. Six weeks before inoculation, viruliferous whitefly numbers were increased by adding additional noninfected 'Florida Lanai' plants with 7 to 10 leaves to screened cages. Seed of lines to be inoculated were sown in flats containing Black Beauty spent coal (Reed Minerals Div., Highland Industries, Tampa, Fla.). Seedlings were transplanted at the cotyledon stage to styrofoam trays $\left(\right.$ cell size $\left.=3.8 \mathrm{~cm}^{2}\right)$ where they were grown to the three-leaf stage in a fiberglass house with ambient light and temperature. The trays were moved to a greenhouse with whitefly-proof screens and were inoculated for $14 \mathrm{~d}$, using one infested source plant for every 512 seedlings (four trays). Trays were moved periodically, plants were fertilized at necessary, and source plants were shaken daily to provide a uniform distribution of whiteflies in the chamber. Viruliferous whiteflies on the inoculated seedlings were moved to the field with the transplants where they were allowed to reproduce freely.
$P_{1}(0.73)$

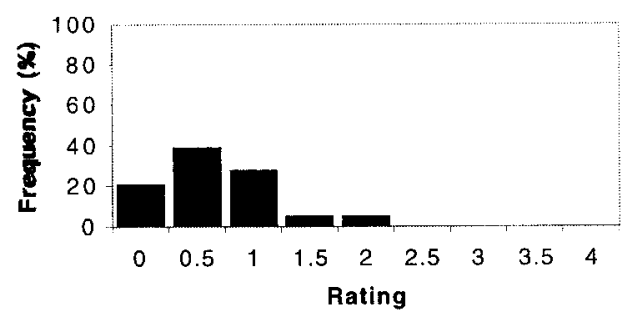

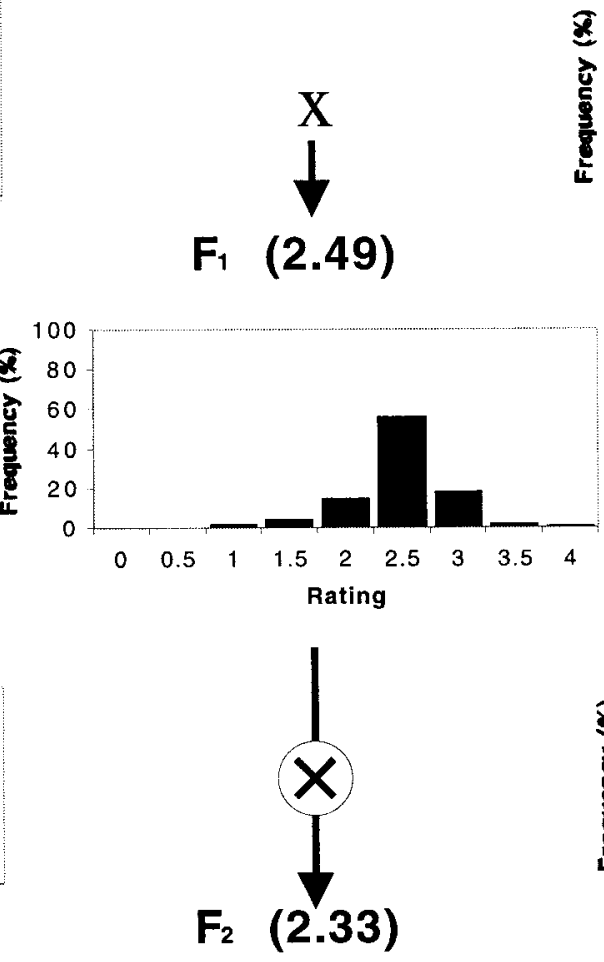
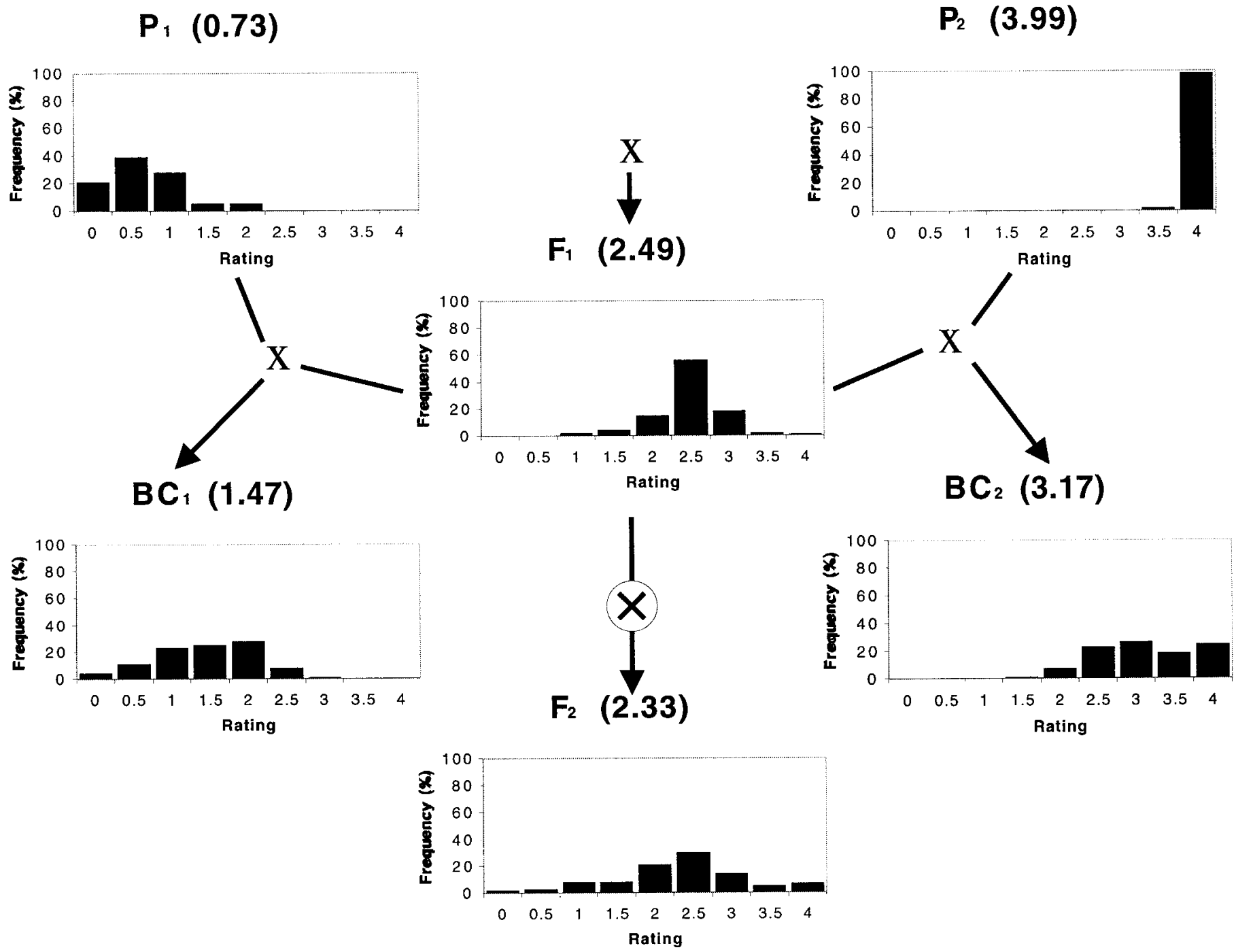

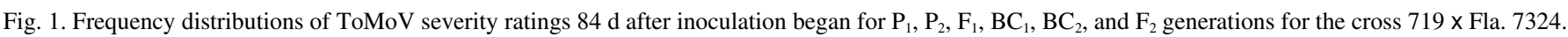


Evaluation. Inoculated 35-d-old seedlings were transplanted in Aug. 1997 and Feb. 1998 into field beds (EauGallie fine sand) that were $20 \mathrm{~cm}$ high, $76 \mathrm{~cm}$ wide, and were spaced on $152 \mathrm{~cm}$ centers. Plants were spaced $45 \mathrm{~cm}$ apart within rows. The beds were fumigated previously (67\% methyl bromide: $33 \%$ chloropicrin at $239 \mathrm{~kg} \cdot \mathrm{ha}^{-1}$ ) and covered with black polyethylene mulch in the spring or white polyethylene mulch in the fall. Plants were rated for ToMoV severity at $21 \mathrm{~d}$ intervals: 42,63 , and $84 \mathrm{~d}$ after inoculation began (DAI). The rating scale was from 0 to 4 as documented by Scott et al. (1995), where $0=$ no symptoms and $4=$ severe symptoms and stunting. Intermediate scores $(0.5,1.5$, etc.) were incorporated to obtain more accurate distributions of disease severity ratings. Data from the rating 84 DAI were used for inheritance analysis to record the most accurate resistance levels of plants and to minimize the possibility of escapes. This was possible, as any seedlings escaping inoculation in the screen chamber were infected in the field by this time (Griffiths, 1998).

IDENTIFICATION OF POLYMORPHISMS. DNA was extracted from new leaves (Doyle and Doyle, 1990) and stored at $-20{ }^{\circ} \mathrm{C}$. Random fragments of DNA were amplified (Williams et al., 1990) using single 10-mer oligonucleotide primers (Biotechnology Lab., University of British Columbia, Vancouver, British Columbia, Canada) in a modified polymerase chain reaction (PCR) buffer (0.5 м Tris pH 8.3, $10 \mathrm{~mm} \mathrm{MgCl}_{2}, 10 \mathrm{~mm}$ Tartrazine, $14 \%$ w/v Ficoll), and fragments were separated by gel electrophoresis on a $1.2 \%$ agarose gel. RAPD polymorphisms were generated using standard PCR procedures (Williams et al., 1990) for 45 cycles in a Stratagene robocycler. Each cycle consisted of $60 \mathrm{~s}$ at $94{ }^{\circ} \mathrm{C}, 60 \mathrm{~s}$ at $35^{\circ} \mathrm{C}$ and $90 \mathrm{~s}$ at $72^{\circ} \mathrm{C}$. Gel banding patterns were visualized under ultraviolet light after staining with ethidium bromide $\left(4 \mathrm{ng} \cdot \mathrm{mL}^{-1}\right)$, and gel sequences were recorded on Type 55 Polaroid film (Polaroid Corp., Cambridge, Mass.). Polymorphic RAPD bands were identified and recorded.

Statistical analysis. Adequacy of the additive-dominance model was tested using the joint scaling test which uses weighted least squares estimates based on the generation means (Cavalli, 1952). Goodness of fit to the model was tested using chi-square distribution. If the joint scaling test indicated adequacy of the additive-dominance model, epistatic effects were considered insignificant. The generation means analysis was based on the means and standard errors of the $\mathrm{P}_{1}, \mathrm{P}_{2}, \mathrm{~F}_{1}, \mathrm{BC}_{1}, \mathrm{BC}_{2}$, and $\mathrm{F}_{2}$ populations according to Mather and Jinks (1982), and the analysis was calculated, using a spreadsheet program $(\mathrm{Ng}, 1990)$. Using this program, the number of effective factors $(\mathrm{k})$ was calculated (Wright, 1934) and estimates of broad-sense heritability (Mahmud and Kramer, 1951) and narrow-sense heritability (Warner, 1952) were made. Calculations of environmental variation were based on variation of the $\mathrm{P}_{1}, \mathrm{P}_{2}$, and $\mathrm{F}_{1}$ populations (Allard, 1960). Data from the fall and spring were compared by analysis of variance (ANOVA) to confirm that no significant differences were observed between means and variances in the two seasons (Griffiths, 1998). Data sets were then pooled to allow a more powerful analysis using the larger population size.

Morphological markers ( $s p$ or $c$ ), polymorphic RAPD markers, and disease severity were scored for each plant in the $\mathrm{F}_{2}$ generations. The RAPD marker genotypes were tested for significant associations with disease severity, using "SAS for Windows" (SAS Inst., Inc., 1997) general linear model analysis. Segregation of the polymorphisms was determined for the $\mathrm{F}_{2}$ populations derived from both $719 \times 7324$ and $729 \times 7613$ crosses, and the data were pooled. Linkage analyses were made between segregating phenotypic and molecular markers, using Joinmap 1.3 (Stam, 1993).

\section{Results}

Data sets from the fall and spring were compared by ANOVA, and the differences for the two seasons were nonsignificant $(P=$ $0.91)$, although a season $\times$ generation interaction was found $(P=$ $0.011)$. Analysis of the results for each of the six generations revealed a significant difference $(P<0.01)$ between the mean ratings of the $\mathrm{BC}_{2}$ populations for Fall 1997 (mean disease severity $=3.3$ ) and Spring 1998 (mean disease severity $=3.0$ ). The respective $\mathrm{P}_{1}, \mathrm{P}_{2}, \mathrm{~F}_{1}, \mathrm{BC}_{1}$, and $\mathrm{F}_{2}$ generations did not differ significantly between the two seasons. As the interpretation of results from both seasons was the same, the two data sets were pooled to improve sampling and simplify the presentation of inheritance data. The $\mathrm{F}_{2}$ populations derived from $719 \times 7324$ were scored for $s p$ phenotype, and segregated for indeterminate $(s p+)$ : determinate plants $(s p)$ with a ratio of $204: 75$, fitting the expected ratio of $3: 1\left(\chi^{2}=0.50, P>0.1\right)$. The mean disease severity of determinate plants (3.04) was significantly higher $(P$ $<0.001)$ than the mean disease severity of indeterminate plants (2.04).

ToMoV resistance was not complete in the resistant parent and frequency distributions for the pooled data set showed the mean of the $F_{1}$ population was skewed slightly to the susceptible side of the midparent value (2.36) (Fig. 1). The $\mathrm{BC}_{1}$ population mean was between the $\mathrm{P}_{1}$ and $\mathrm{F}_{1}$ means, and the $\mathrm{BC}_{2}$ population mean was between the $F_{1}$ and $P_{2}$ means. The $F_{2}$ population segregated continuously, with its mean (2.33) near the midparent value. Thus, the data indicated that the gene action was mostly additive, but not entirely. The data had an acceptable fit to the additivedominance model using the joint scaling test for the combined data $\left[\chi^{2}(\mathrm{df} 3)=6.83, P=0.1\right.$ to 0.05$]$, indicating that additive and dominance effects accounted for most of the genetic variation without significant epistasis.

Estimates of the additive and dominance effects were made and the variation was found to be mainly additive, with a small dominance effect (Table 1). Additive effects were significant $(P$ $<0.001)$, but no significant dominant effects were found $(P>0.1)$. Broad-sense heritability and narrow-sense heritability were high ( 0.95 and 0.87 , respectively), again indicating that the majority of the genetic variation was caused by additive gene action. The data suggested involvement of 2.29 effective factors.

Of the 800 oligonucleotide primers used (UBC 001-UBC 800 ) for amplification, a total of 34 polymorphic bands [26 coupling $(+)$ and 8 repulsion (-)] were identified between 719 and 7324. One of the primers (UBC 061) amplified both a coupling and repulsion polymorphic band that were linked in repulsion indicating they represented a RAPD length polymorphism between resistant and susceptible plants at this locus. Twelve of the polymorphisms segregated with consistent repeatability in the $\mathrm{F}_{2}$ populations derived from $719 \times 7324$, and seven of these segre-

Table 1. Estimates of components of variation, heritability, and effective factor number from a 719 (LA 1932) x Fla. 7324 cross using combined data from Fall 1997 and Spring 1998.

\begin{tabular}{lc}
\hline \hline Component & Estimate \\
\hline Additive variance & -1.68 \\
Dominance variance & 0.09 \\
Environmental variance & 0.22 \\
Broad-sense heritability & 0.95 \\
Narrow-sense heritability & 0.87 \\
Effective factor number & 2.29 \\
\hline
\end{tabular}


Table 2. Linkage of primers generating polymorphisms in two regions (R1 and R2) on chromosome 6 based on linkage data from two $\mathrm{F}_{2}$ populations derived from $L$. chilense accession LA 1932.

\begin{tabular}{lcc}
\hline \hline Primer no. & Linkage group & Map distance $(\mathrm{cM})$ \\
\hline UBC 169 & R1 & 0 \\
UBC 462 & R1 & 0.4 \\
UBC 395 & R1 & 0.7 \\
UBC 35 & R1 & 0.9 \\
UBC 768 & R1 & 1.5 \\
$s p$ locus & --- & 5.7 \\
$c$ locus & --- & 10.4 \\
UBC 131 & --- & 12.4 \\
UBC 137 & R2 & 39.7 \\
UBC 112 & R2 & 41.7 \\
UBC 236 & R2 & 42.8 \\
UBC 61 & R2 & 43.1 \\
UBC 110 & R2 & 43.6 \\
UBC 374 & R2 & 44.3 \\
\hline
\end{tabular}

gated in the $\mathrm{F}_{2}$ population derived from $729 \times 7613$. The polymorphisms segregated in the $F_{2}$ populations into two linkage groups, designated $\mathrm{R} 1$ and $\mathrm{R} 2$, about $40 \mathrm{cM}$ apart either side of the morphological markers $s p$ and $c$ on chromosome 6 (Table 2).

Region R1 was identified using UBC $169(+)$ and UBC $035(-)$, and region 2 using the codominant marker UBC $061(+/-)$ which amplified a length polymorphism in susceptible and resistant plants. These markers were chosen so that heterozygotes could be identified for the two linkage groups flanking the $s p$ locus. The mean disease ratings were calculated for each of the nine possible marker combinations (Table 3). Plants homozygous for R1 and R2 markers $(++,++)$ were the most resistant plants and were significantly better than plants without either marker $(-,-)$ throughout the season. Region R2 was linked to the $c$ gene on the long arm of chromosome 6 at a distance of $29.3 \mathrm{cM}$ (Table 2). Region R2 was exclusive to lines derived from accession LA 1932 and was associated with potato leaf plants. Plants homozygous for the R1 region $(++,-)$ had effective resistance throughout the season and had significantly lower levels of ToMoV disease severity at the 63 and $84 \mathrm{~d}$ ratings than plants missing both genotypes (-, -). Plants homozygous for the R2 marker (-, ++ ) had lower levels of disease severity earlier in the season (42 DAI) when compared to plants without either marker $(-,-)$, although this difference was not significant. Plants heterozygous for both markers (+-, +-) had significantly lower ToMoV disease severity than plants without either marker $(-,-)$ for all ratings.
Heterozygotes were intermediate to the homozygotes for both markers, suggesting the effects were additive (Fig. 2).

\section{Discussion}

Inheritance and molecular studies complemented one another as they suggest involvement of at least two genes for ToMoV resistance in the populations studied. Determination of gene number was made through effective factor estimates, number of RAPD marker linkage groups associated with ToMoV resistance, and proportions of resistant plants in the $F_{2}$ generations. A distance of $\approx 40 \mathrm{cM}$ was calculated between regions $\mathrm{R} 1$ and $\mathrm{R} 2$, and the regions appear to be separated by a sufficient distance such that the linkage does not affect the statistical estimate of effective factor number.

The resistance obtained was not complete, as minor symptoms were evident in some of the plants of the resistant parent (Fig. 1). Results confirm earlier evidence that more than one gene controlled ToMoV resistance (Scott et al., 1995). As the $\mathrm{F}_{1}$ resistance was intermediate, both parents would require resistance to develop hybrids with adequate resistance. As two genes are involved, this will require considerable effort in a breeding program.

The two linkage groups identified in this study were mapped to phenotypic markers on the long arm of chromosome 6 . The TYLCV-I resistance gene $T y-1$ bred from LA 1969 was mapped previously to the short arm of chromosome 6 . Thus, the two genes introgressed from LA 1932 for ToMoV resistance differ from the Ty-1 gene introgressed from LA 1969 for TYLCV resistance. ToMoV resistant plants derived from accessions LA 1938 and LA 2779 contain markers that have been mapped to chromosome 6 in a homologous region to the $T y-1$ gene (Griffiths, 1998). Other ToMoV resistance genes probably exist in other chromosomal regions, particularly in LA 2779 derived material. Combining genes from geminivirus resistant lines derived from different accessions of $L$. chilense may result in higher levels of resistance to ToMoV and/or other geminiviruses. Moreover, combining $L$. chilense genes with genes from other sources might be useful in obtaining resistance to various geminiviruses (Vidavsky et al., 1998). Available markers could be useful in synthesizing gene combinations for testing against various geminiviruses to identify the most effective combinations.

It was noted previously that indeterminate plants had greater ToMoV resistance than determinate plants (Scott et al., 1995). Analysis of the segregation of the $s p$ gene with ToMoV resistance revealed a significant association of indeterminate plants $(s p+)$

Table 3. Effect of regions R1 and R2 on ToMoV resistance determined using primers UBC 169 (+), UBC 035 (-), and UBC 061 (+/-).

\begin{tabular}{|c|c|c|c|c|}
\hline \multirow[b]{2}{*}{ Region } & \multirow{2}{*}{$\begin{array}{l}\text { Marker } \\
\text { genotype }\end{array}$} & \multicolumn{3}{|c|}{ Rating $^{\mathrm{z}}$} \\
\hline & & $42 \mathrm{~d}$ & $63 \mathrm{~d}$ & $84 \mathrm{~d}$ \\
\hline [1] R1 (++), R2 (++) & $169,061(+)$ & $0.6 c^{y}$ & $0.8 \mathrm{~d}$ & $1.0 \mathrm{~d}$ \\
\hline [2] R1 (++), R2 (+ -) & $169,061(+), 061(-)$ & $1.0 \mathrm{bc}$ & $1.3 \mathrm{~cd}$ & $1.3 \mathrm{~cd}$ \\
\hline [3] R1 (++), R2 (- -) & $169,061(-)$ & $1.4 \mathrm{abc}$ & $1.8 \mathrm{bc}$ & $1.8 \mathrm{bc}$ \\
\hline [4] R1 (+-), R2 (+ +) & $169,035,061(+)$ & $0.8 \mathrm{bc}$ & $1.0 \mathrm{~d}$ & $1.0 \mathrm{~d}$ \\
\hline [5] R1 (+-), R2 (+-) & $169,035,061(+), 061(-)$ & $1.3 \mathrm{bc}$ & $1.8 \mathrm{bc}$ & $1.8 \mathrm{bc}$ \\
\hline [6] R1 (+-), R2 (--) & $169,035,061(-)$ & $1.6 \mathrm{ab}$ & $2.2 \mathrm{ab}$ & $2.2 \mathrm{~b}$ \\
\hline [7] $\mathrm{R} 1(--), \mathrm{R} 2(++)$ & $035,061(+)$ & $1.5 \mathrm{abc}$ & $2.4 \mathrm{ab}$ & $2.8 \mathrm{a}$ \\
\hline [8] R1 (--), R2 (+-) & $035,061(+), 061(-)$ & $1.6 \mathrm{ab}$ & $2.5 \mathrm{ab}$ & $3.2 \mathrm{a}$ \\
\hline [9] R1 (--), R2 (--) & $035,061(-)$ & $2.2 \mathrm{a}$ & $2.9 \mathrm{a}$ & $3.1 \mathrm{a}$ \\
\hline
\end{tabular}

${ }^{\mathrm{z}}$ Rating time in days after inoculation began (DAI).

y Mean separation within columns by Duncan's multiple range test, at $P \leq 0.05$. 
42 DAl

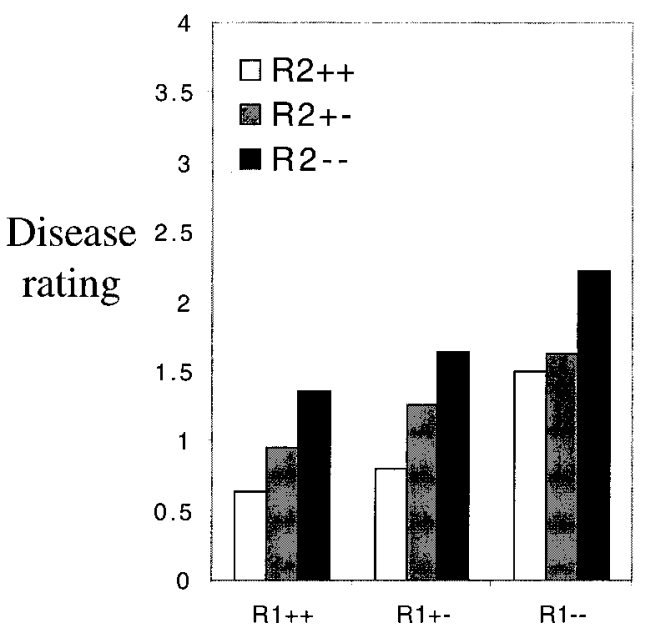

84 DAl

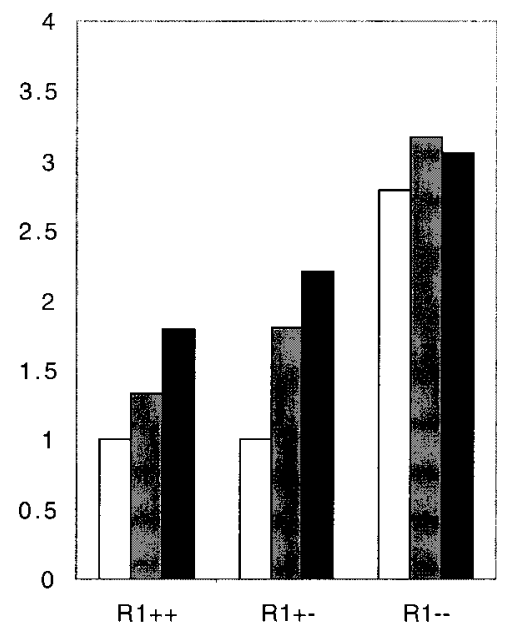

Laterrot (derived from L. chilense LA 1969 and 'TyKing') and in the TYLCV tolerant landrace 'TyKing'. These genotypes also had resistance to ToMoV (data not presented) and may have a geminivirus resistance gene in the same region as LA 1932 derived lines.

Region R1 will probably be the most difficult region to select due to its close linkage to the sp locus. A determinate inbred more resistant than 729 has been developed and has been comparable to most resistant indeterminate inbreds (data not presented). Crossovers to reduce linkage drag will be required for cultivar development to succeed, but the high resistance level indicates that resistance genes have been transferred to a determinate inbred. Consequently, it should be possible to develop determinate cultivars with resistance derived from LA 1932. RAPD markers that can be dissociated from deleterious traits also need to be identified before resistance can be selected efficiently with molecular markers. Use of marker-assisted selection (MAS) would greatly facilitate development of ToMoV resistant cultivars by allowing two crosses per year, as opposed to the present system of one cross every 2 years. MAS would also reduce the need for inoculation with viruliferous whiteflies that can serve as a source of unwanted ToMoV contamination for surrounding tomato production. The ToMoV resistance derived from $L$. chilense may also be useful against other geminiviruses. Several ToMoV resistant lines have been tested against geminiviruses, including TYLCV, in various regions around the world, and many have shown resistance (Scott et al., 1995 and data not presented). However, no single genotype has been resistant to all geminiviruses tested, indicating the need for further work to determine the combination of genes required for resistance to the geminivirus of interest. Genes with broad spectrum resistance would be desirable given the proliferation of geminivirus diseases (Polston and Anderson, 1997) and the likelihood of new viruses emerging should an existing one decline due to the use of resistant cultivars.

\section{Literature Cited}

Abouzid, A.M., J.E. Polston, and E. Hiebert. 1992. The nucleotide sequence of tomato mottle virus, a new geminivirus isolated from tomatoes in Florida. J. Gen. Virol. 73:3225-3229.

Allard, R.W. 1960. Quantitative inheritance, p. 75-88. In: Principles of plant breeding. Wiley, New York.

Cavalli, L.L. 1952. An analysis of linkage of quantitative inheritance, p. 135-144. In: E.C.R. Reeve and C.H. Waddington (eds.). Quantitative inheritance. H.M. Stat. Off., London.

Doyle, J. and J. Doyle. 1990. Isolation of plant DNA from fresh tissue. Focus 12:13-15.

Griffiths, P.D. 1998. Inheritance and linkage of geminivirus resistance genes derived from Lycopersicon chilense Dunal in tomato (Lycopersicon esculentum Mill.). PhD diss., Univ. of Florida, Gainesville.

Hassan, A., H. Mazyad, S. Moustafa, S. Nassar, M. Nakhla, and W. Sims. 1984. Inheritance of resistance to tomato yellow leaf curl virus derived from Lycopersicon cheesmanii and Lycopersicon hirsutum. HortScience 19:574-575.

Kasrawi, M.A. 1989. Inheritance of resistance to tomato yellow leaf curl virus in Lycopersicon pimpinellifolium. Plant Dis. 73:435-437.

Khush, G.S. and C.M. Rick. 1968. Cytogenetic analysis of the tomato genome by means of induced deficiencies. Chromosoma 23:452-484.

chromosome 6 than the $c$ locus mapped previously. Potato lea was also observed in TYLCV resistant lines received from Henri 
Kring, J.B., D.J. Schuster, J.F. Price, and G.W. Simone. 1991. Sweetpotato whitefly-vectored geminivirus on tomato in Florida. Plant Dis. 75:1186.

Mahmud, I. and H.H. Kramer. 1951. Segregation for yield, height and maturity following a soybean cross. Agron. J. 44:605-608.

Mather, K. and J.L. Jinks. 1982. Biometrical genetics. $3^{\text {rd }}$ ed. Chapman and Hall, London.

Navot, N., E. Pichersky, Z.Muhammad, D. Zamir, and H. Czosnek. 1991. Tomato yellow leaf curl virus: A whitefly transmitted geminivirus with a single genomic component. Virology 185:151-161.

Ng., T.J. 1990. Generation means analysis by microcomputer. HortScience 25:363.

Pilowsky, M. and S. Cohen. 1974. Inheritance of resistance to tomato yellow leaf curl virus in tomatoes. Phytopathology 64:632-635.

Pilowsky, M. and S. Cohen. 1990. Tolerance to tomato yellow leaf curl virus derived from Lycopersicon peruvianum. Plant Dis. 74:248-250.

Polston, J.E. and P.K. Anderson. 1997. The emergence of whiteflytransmitted geminiviruses in tomato in the Western Hemisphere. Plant Dis. 81:1358-1369.

Polston, J.E., E. Hiebert, R.J. McGovern, P.A. Stansly, and D.J. Schuster. 1993. Host range of tomato mottle virus, a new geminivirus infecting tomato in Florida. Plant Dis. 77:1181-1184.

Rick, C.M. and L. Butler. 1956. Cytogenetics of tomato. Adv. Genet. 8:267-382.

SAS Institute, Inc. 1997. SAS users guide. SAS Inst., Inc., Raleigh, N.C.

Schuster, D.J., T.F. Mueller, J.B. Kring, and J.F. Price. 1990. Relationship of the sweetpotato whitefly to a new tomato fruit disorder in Florida. HortScience 25:1618-1620.

Scott, J.W. and D.J. Schuster. 1991. Screening of accessions for resistance to the Florida tomato geminivirus. Tomato Genet. Coop. Rpt. 41:48-50.

Scott, J.W., M.R. Stevens, J.H. Barten, C.H. Thome, J.E. Polston, D.J. Schuster, and C.A. Serra. 1995. Introgression of resistance to whitefly- transmitted geminiviruses from Lycopersicon chilense to tomato, $\mathrm{p}$. 357-367. In: D. Gerling and R.T. Mayer (eds.). Bemisia: Taxomomy, biology, damage, control and management. Intercept, Andover, United Kingdom.

Stam, P. 1993. Construction of integrated genetic linkage maps by means of a new computer package: Joinmap. Plant J. 3:739-744.

Tanksley, S., M. Ganal, J. Prince, M. de Vincente, M. Bonierabale, P. Broun, T. Fulton, J. Giovanonni, S. Grandillo, G. Martin, R. Messeuguer, J. Miller, L. Miller, A. Paterson, O. Pineda, M. Roder, R. Wing, W. Wu, and N. Young. 1992. High density molecular linkage maps of the tomato and potato genomes. Genetics 132:1141-1160.

Vidavsky, F., S. Leviatov, J. Milo, H.D. Rabinowitch, N. Kedar, and H. Czosnek. 1998. Response of tolerant breeding lines of tomato, Lycopersicon esculentum, originating from three different sources $(L$. peruvianum, L. pimpinellifolium, and L. chilense) to early controlled inoculation by tomato yellow leaf curl virus (TYLCV). Plant Breeding 117:165-170.

Warner, J.N. 1952. A method for estimating narrow-sense heritability. Agron. J. 44:427-430.

Weide, R., M.F. van Wordragen, R.K. Lankhorst, R. Verkerk, C. Hanhart, T. Liharska, E. Pap, P. Stam, P. Zabel, and M. Koornneef. 1993. Integration of the classical and molecular linkage maps of tomato chromosome 6. Genetics 135:1175-1186.

Williams, S., A. Kubelik, K. Livak, J. Rafalski, and S. Tingey. 1990. DNA polymorphisms amplified by arbitrary primers are useful as genetic markers. Nucleic Acids Res. 18:6531-6535.

Wright, S. 1934. The results of crosses between inbred strains of guinea pigs differing in number of digits. Genetics 19:537-551.

Zamir, D., I.E. Michelson, Y. Zakay, N. Navot, M. Zeidan, M. Sarfatti, Y. Eshed, E. Harel, T. Pleban, H. van Oss, N. Kedar, H.D. Rabinowitz, and H. Czosnek. 1994. Mapping and introgression of a tomato yellow leaf curl virus tolerance gene, Ty-1. Theor. Appl. Genet. 88:141-146. 